\title{
RECTIFICATION RECTIFIED
}

In Chartbrook Ltd v Persimmon Homes Ltd [2009] UKHL 38, [2009] A.C. 1101, Lord Hoffmann expressed the view that a contract could be rectified for common mistake even where one party was not actually mistaken: it was sufficient that a reasonable observer would conclude, objectively, that both parties had made a common mistake. The other members of the House of Lords agreed with Lord Hoffmann's speech, but his Lordship's views on rectification were, strictly, obiter. This left the law in a troublesome position: should judges follow Lord Hoffmann's lead, or continue to apply the orthodox test that required both parties actually (or "subjectively") to have made a mistake? The answer to this question has not been clear for over a decade. In Daventry District Council v Daventry \& District Housing Ltd [2011] EWCA Civ 1153; [2012] 1 W.L.R. 1333 the parties assumed, without further argument, that the objective approach to rectification favoured in Chartbrook should be applied, and the Supreme Court frustratingly refused permission to appeal. However, in FSHC Group Holdings Ltd v Glas Trust Corporation Ltd [2019] EWCA Civ 1361 the Court of Appeal was able to examine common mistake rectification thoroughly. In an excellent judgment, Leggatt L.J. (with whom Rose L.J. and Flaux L.J. joined) restored traditional orthodoxy and rejected the objective approach to establishing a common mistake where the parties had not concluded a binding contact before producing the written instrument.

FSHC was a parent company which entered into a private equity financing transaction in 2012 that required it to provide security over a shareholder loan. In 2016, its lawyers spotted that the relevant security documentation had either never been provided or could not be located. They drafted Accession Deeds to provide that security, which FSHC entered into with the defendant bank. By mistake, the Accession Deeds were drafted such that much more onerous obligations were undertaken by FSHC than was required.

FSHC successfully brought a claim to rectify the deeds by deleting the additional obligations that were not necessary. The trial judge found that the lawyers and relevant directors on both sides all subjectively intended the Accession Deeds only to provide the missing security and no more, and that this was also what a reasonable observer would understand the parties to have intended. The Court of Appeal agreed.

The decision is therefore explicable on both a "subjective" or "objective" approach to common mistake rectification, and the result must be right. The 
case is significant since it "provide[d] the opportunity for an appellate court to clarify the correct test to apply in deciding whether the written terms of a contract may be rectified because of a common mistake" (at [1]). After careful consideration of the development of rectification in contract law, Leggatt L.J concluded (at [176]):

... we are unable to accept that the objective test of rectification for common mistake articulated in Lord Hoffmann's obiter remarks in the Chartbrook case correctly states the law. We consider that we are bound by authority, which also accords with sound legal principle and policy, to hold that, before a written contract may be rectified on the basis of a common mistake, it is necessary to show either (1) that the document fails to give effect to a prior concluded contract or (2) that, when they executed the document, the parties had a common intention in respect of a particular matter which, by mistake, the document did not accurately record. In the latter case it is necessary to show not only that each party to the contract had the same actual intention with regard to the relevant matter, but also that there was an "outward expression of accord" meaning that, as a result of communication between them, the parties understood each other to share that intention.

This paragraph will be cited regularly in future claims for rectification.

The most usual fact-pattern concerns (2), and the departure from Chartbrook is welcome. As previously argued in this Journal (see [2016] C.L.J. 62) that decision was unsatisfactory. The objective approach of Lord Hoffmann made it too easy for the court to say that there was a common mistake, even where one party was not actually mistaken; this blurred the line between rectification for common mistake and unilateral mistake. In principle, there is no reason why the objective interpretation of an earlier, informal accord should trump the objective interpretation of a later, formal written contract; indeed, the latter should carry greater weight. As a matter of policy, rectification should be narrow and difficult to prove: the formal written document should presumptively be upheld. And as a matter of precedent, Chartbrook was only obiter and founded on shaky foundations; for example, Lord Hoffmann relied upon the decision of the Court of Appeal in Britoil plc v Hunt Overseas Oil Inc [1994] C.L.C. 561, but in that decision the majority (Hoffmann L.J. dissenting) endorsed the traditional, subjective approach to common mistake. In supporting the majority in Britoil, the thrust of the judgment in FSHC should be welcomed. The test provided by the Court of Appeal is clear and authoritative, 
and there is much in the judgment that deserves emphasis. For reasons of space, only two controversial issues can now be highlighted.

First, the "outward expression of accord" has been elevated to a substantive requirement in a claim for rectification for common mistake. This notion has been controversial since its recognition in Joscelyne $v$ Nissen [1970] 2 Q.B. 86. Before $F S H C$, it was widely understood that this was only an evidential requirement (e.g. Munt v Beasley [2006] EWCA Civ 370). But Leggatt L.J. insisted that rectification could only be granted to correct mistakes in recording what the parties have agreed, and that there would be no injustice in refusing to grant rectification where the parties have not shared their intentions with one another. At first blush, this may seem harsh: if it can be proved that both $A$ and $B$ intended $X$, but the contract states $Y$, it might appear fair to rectify the contract to say $X$ even if $A$ and $B$ did not communicate their intentions to one another. In practice, however, the difference between treating the "outward expression of accord" as an evidential or substantive requirement is not great. It was probably most important in the context of amendments of pension schemes, which are generally not contractual anyway (see [78]-[79]); and, importantly, "the communication necessary to establish an outwardly expressed accord or common intention which each party understands the other to share need not involve declaring that agreement or intention in express terms. The shared understanding may be tacit" (at [81]). That includes understandings that were so obvious as to go without saying. This broad approach to shared understandings will accommodate many cases; instances where it can be proved that both parties independently made the same mistake but did not communicate their intentions - even tacitly - are likely to be very rare.

Secondly, distinguishing between situations (1) and (2) at [176] may lead to fine distinctions being drawn. Should it matter whether a prior concluded contract was reached? The answer appears to be Yes, because if a contract has already been concluded then rectification may be viewed as a branch of specific performance: granting rectification ensures that the prior concluded contract is enforced. It must be shown that the parties intended simply to record their binding agreement in writing, and were mistaken about the contents of that document. In (2), by contrast, there is no prior contract to specifically enforce. Moreover, distinguishing between (1) and (2) helps to explain earlier authorities binding on the Court of Appeal (see Ruddell [2014] L.M.C.L.Q. 48; the notorious decision in Frederick E Rose (London) Ltd $v$ William H Pim Jnr \& Co Ltd [1953] 2 Q.B. 450 can perhaps best be explained on the basis that the parties entered into a prior contract, rather than the difficult alternatives discussed in FSHC at [63]-[71])). In any event, the fact-pattern in the most problematic cases 
(such as Chartbrook, Daventry, and FSHC) do not concern a prior contract, and it is in (2) where the greatest difficulties have arisen.

On one view, the Court of Appeal did not need to consider the law of rectification so extensively on the facts of $F S H C$. But setting out the correct approach to rectification was a necessary step in the court's reasoning and could reasonably be viewed as ratio (see $R$ (Youngsam) $v$ Parole Board [2019] EWCA Civ 229; [2019] 3 W.L.R. 33 at [48]-[59]). Even if not, earlier binding authorities discussed in FSHC mean that paragraph [176] should be applied by the courts unless and until the Supreme Court decides otherwise.

Lord Sumption has observed that "the Supreme Court has begun to withdraw from the more advanced positions seized during the Hoffmann offensive" ([2017] O.U.C.L.J. 301, 313) as regards interpretation (e.g. Arnold v Britton [2015] UKSC 36; [2015] A.C. 1619) and implication (e.g. Marks \& Spencer plc v BNP Paribas Securities Services Trust Co (Jersey) Ltd [2015] UKSC 72; [2016] A.C. 742). In FSHC, the Court of Appeal has taken a similar opportunity to depart from Lord Hoffmann's views on rectification. Where the parties only envisage being bound upon signing a contract, the best evidence of their objective intentions is the formal, written document. For that contract to be rectified for common mistake, both parties must have actually made a mistake.

PAUL S. DAVIES

University College London 